\title{
Polycation Induced Potential Dependent Structural Transitions of Oligonucleotide Monolayers on Au(111)-Surfaces
}

Salvatore, Princia; Karlsen, Kasper Kannegård; Hansen, Allan Glargaard; Zhang, Jingdong; Nichols, Richard J.; Ulstrup, Jens

Published in:

Journal of the American Chemical Society

Link to article, DOI:

10.1021/ja306877s

Publication date:

2012

Document Version

Publisher's PDF, also known as Version of record

Link back to DTU Orbit

Citation (APA):

Salvatore, P., Karlsen, K. K., Hansen, A. G., Zhang, J., Nichols, R. J., \& Ulstrup, J. (2012). Polycation Induced Potential Dependent Structural Transitions of Oligonucleotide Monolayers on Au(111)-Surfaces. Journal of the American Chemical Society, 134, 19092-19098. https://doi.org/10.1021/ja306877s

\section{General rights}

Copyright and moral rights for the publications made accessible in the public portal are retained by the authors and/or other copyright owners and it is a condition of accessing publications that users recognise and abide by the legal requirements associated with these rights.

- Users may download and print one copy of any publication from the public portal for the purpose of private study or research.

- You may not further distribute the material or use it for any profit-making activity or commercial gain

- You may freely distribute the URL identifying the publication in the public portal 


\title{
$\mathrm{J}$

\section{Polycation Induced Potential Dependent Structural Transitions of Oligonucleotide Monolayers on Au(111)-Surfaces}

\author{
Princia Salvatore, ${ }^{\dagger}$ Kasper K. Karlsen, ${ }^{\dagger}$ Allan G. Hansen, ${ }^{\dagger}$ Jingdong Zhang, ${ }^{\dagger}$ Richard J. Nichols, ${ }^{\S}$ \\ and Jens Ulstrup ${ }^{\dagger} * *$
}

${ }^{\dagger}$ Department of Chemistry, Building 207, and Nano•DTU, Technical University of Denmark, DK-2800 Kongens Lyngby, Denmark ${ }^{\ddagger}$ Department of Physics, Chemistry and Pharmacy, University of Southern Denmark, Campusvej 55, DK-5230, Odense M, Denmark

${ }^{\S}$ Department of Chemistry, University of Liverpool, Liverpool L69 7ZD, United Kingdom

\section{Supporting Information}

\begin{abstract}
We have studied self-assembled molecular monolayers (SAMs) of several 3 '-C3-SH conjugated single-strand (ss) and double-strand (ds) 20-base oligonucleotides (ONs) immobilized on single-crystal, atomically planar $\mathrm{Au}(111)$-electrode surfaces in the presence of the triply positively charged base spermidine (Spd). This cation binds strongly to the polyanionic $\mathrm{ON}$ backbone and stabilizes the ds-form relative to the ss-form. A combination of chemical $\mathrm{ON}$ synthesis, melting temperature measurements, cyclic voltammetry $(\mathrm{CV})$, and in situ scanning tunneling microscopy (STM) in aqueous biological buffer under electrochemical potential control was used. Spd binding was found to increase notably the ds-ON melting temperature. $\mathrm{CV}$ displays capacitive features associated with ss- and ds-ON. A robust capacitive peak around $-0.35 \mathrm{~V}$ versus saturated calomel electrode (SCE), specific to ds$\mathrm{ON}$ and highly sensitive to base pair mismatches, was consistently observed. The peak is likely to be caused by surface structural reorganization around the peak potential and located close to reported peak potentials of several DNA intercalating or covalently tethered redox molecules reported as probes for long-range electron transfer.
\end{abstract}

\section{INTRODUCTION}

DNA-based molecules transfer electronic charge (electrons or holes) through the molecular double-strand (ds) DNA structure. $^{1-13}$ Charge transfer in homogeneous solution is broadly restricted to photoinduced electron or hole transfer through the double-strand with dynamically induced local stacking $^{3,4}$ or polaron formation ${ }^{14,15}$ as possible prerequisites. Interfacial electrochemical DNA-conductivity ${ }^{16-22}$ and recently conductivity in scanning tunneling microscopy (STM) and nanogap electrode configurations ${ }^{23-30}$ have also been addressed. In these respects, DNA electron transfer (ET) follows many studies of ET through proteins in solution, ${ }^{31,32}$ twodimensional films at pure and modified electrode surfaces, ${ }^{33-36}$ and at the single-molecule level of functional ET proteins. ${ }^{35-38}$ As for protein ET, views on DNA conductivity rest on concepts from molecular ET science ${ }^{39,40}$ such as superexchange, "vibrationally assisted tunnelling" or "hopping" between DNA base pairs, ${ }^{41,42}$ and concepts of small and large polarons. ${ }^{14,15}$ In comparison with proteins, DNA-based molecular electronic conductivity displays, however, differences which are only partly understood, notably:

- DNA-based charge transport in homogeneous solution involves intercalation or covalently tethered donor and acceptor molecular units. ${ }^{1-13} \mathrm{ET}$, or more commonly hole transport, is initiated by donor or acceptor electronic excitation followed by positive (hole) or negative (electron) charge transmission through the ds. The molecular excited state thus opens ET "hopping" channels, not immediately accessible in the ground state. ET in protein systems is also frequently, but far from always, initiated by photoexcitation followed by electron tunneling, while transmission of radical states in thermal ET through the peptide structure is less important.

- DNA-based hopping facilitates charge transfer over distances which are sometimes very long (100-200 Å). Such channels are opened by the diffusive character of the hopping process, ${ }^{41,42}$ which resembles charge or excitation diffusion in other systems such as redox polymers $^{43}$ or light-harvesting antenna systems in the photosynthetic membrane systems. ${ }^{44}$

- High-energy radical states may also be involved in singlemolecule (or a few molecules) conductivity when the DNA molecules are immobilized between a pair of nanogap electrodes. ${ }^{45}$ Large bias voltages $(\geq 1 \mathrm{~V})$ are mostly used in solid state and ultrahigh vacuum. The low-energy DNA conductivity mechanism in condensed matter environment ${ }^{23-30}$ is, however, more elusive.

- DNA-based molecules functionalized by redox groups also display long-range, almost complete distance independent interfacial electrochemical ET or hole transfer between the electrode and oligonucleotidetethered redox groups. ${ }^{16-22}$ This is different from

Received: July 25, 2012

Published: October 25, 2012 
electrochemical behavior of redox (metallo)proteins. Electrochemical conditions are much "milder" than in photoinduced DNA charge transfer but also sensitive to base matching and other structural order. This is a "puzzle" as hopping cannot involve low-lying electrochemically accessible populated electronic states. Charge delocalization (large polaron formation ${ }^{14,15,46}$ ) may be a clue to lower electronic energies and distance insensitivity of interfacial electrochemical ET. Cationic condensation, ${ }^{47,48}$ and strong binding of multiply charged counterions may be other factors.

In this report, we address polycation binding to single-strand (ss) and ds oligonucleotides (ONs) immobilized on gold surfaces via thiol linkers by interfacial electrochemistry. Our approach follows three lines: (a) We have used single-crystal, atomically planar $\mathrm{Au}(111)$-electrodes. Such surfaces enhance voltammetric sensitivity compared with polycrystalline Auelectrodes and has only recently been reported for DNA-based molecules; ${ }^{25}$ (b) the single-crystal voltammetric DNA data have been supported by electrochemical scanning tunneling microscopy (in situ STM) directly in the aqueous buffer medium for biological DNA function. (c) As noted, we have focused on the role of electrostatic polycation binding to surface immobilized ss- and ds-ONs of variable length and base composition.

Physical properties of the polyanionic ON molecules are sensitive to counterions and polycations in particular. ${ }^{49-56}$ These complex molecular charge distributions are further affected by external electric fields expectedly reflected in capacitive voltammetric signals around the potential of zero charge in ways distinct for the ss- and ds-form. Polycation binding stabilizes the ds-form. A spectacular reflection of the sophisticated electrostatic interactions among counterion controlled ds-ONs is polycation induced columnar stacking of long ONs as foreseen theoretically by Kornyshev and Leikin, ${ }^{46,47}$ and substantiated by Sneddon and associates. ${ }^{56}$ These achievements have prompted novel views of long-range cellular protein-free ("telepathic") DNA interactions and packing.

We first attempted to enhance the stability of Faradaic voltammetric signals of anthraquinone monosulfonate (AQMS, Figure 1$)^{19}$ intercalated in short (13- and 20-base pair) ds-ONs on electrochemical single-crystal $\mathrm{Au}(111)$-surfaces, by binding of the triply positively charged counterion spermidine (Spd, Figure 1), a prime target for enhancing both ds-formation and columnar stacking. Spd was, however, found to cause a strong interfering non-Faradaic ON signal close to the AQMS peak

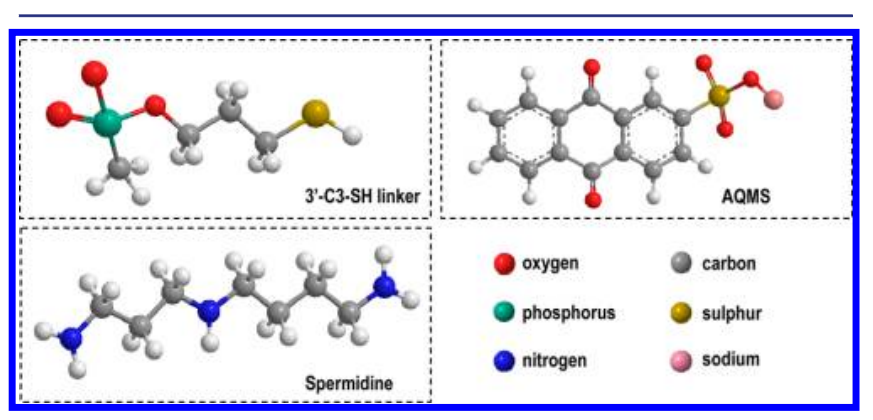

Figure 1. Molecular structure of $3^{\prime}-\mathrm{C} 3-\mathrm{SH}$ linker (top, left), anthraquinone-2-sulfonic acid sodium salt (AQMS) (top, right) and spermidine (bottom). potential $(-450 \mathrm{mV}$ vs $\mathrm{SCE})$. We have studied this nonFaradaic signal systematically.

\section{EXPERIMENTAL SECTION}

2.1. Chemicals and Oligonucleotides. The electrolyte solution, $50 \mathrm{mM} \mathrm{KH} \mathrm{PO}_{4} / \mathrm{K}_{2} \mathrm{HPO}_{4}, 10 \mathrm{mM} \mathrm{NaCl}$, and $10 \mathrm{mM}$ spermidine trihydrochloride ( $\mathrm{pH}$ 6.5), was prepared from $\mathrm{KH}_{2} \mathrm{PO}_{4}$ (SigmaAldrich, 99.99\%), $\mathrm{K}_{2} \mathrm{HPO}_{4}$ (Fluka, 99.99\%), $\mathrm{NaCl}$ (Fluka, $\geq 99.5 \%$ ), Spd $3 \mathrm{HCl}$ (Sigma, $\geq 99.5 \%$ ) and Millipore water $(18.2 \mathrm{k} \Omega \mathrm{cm})$. Anthraquinone-2-sulfonic acid, sodium salt monohydrate (Acros Organics, 90\%) was used as intercalating agent, 6-mercapto-1-hexanol (MCH) (Aldrich, 97\%) as diluent for DNA monolayers.

Thiol-modified ONs were synthesized at the $1.0 \mu \mathrm{mol}$ scale using an automated DNA synthesizer (Perspective Biosystems Expedite, MA). ${ }^{57}$ Standard cycle procedures were applied for unmodified phosphoramidites using $0.45 \mathrm{M}$ solution of $1 \mathrm{H}$-tetrazole as activator. Thiol-modifier C3 S-S (Glen Research, Sterling, VA) was used without purification for conjugation of $3^{\prime}-\mathrm{C} 3-\mathrm{SH}$ linker (Figure 1). Thiol-modified ONs were desalted using commercial NAP-10 columns (GE Healthcare, Buckinghamshire, U.K.). Their composition and purity were verified by MALDI-MS analysis and ion-exchange HPLC $(100 \mathrm{~mm} \times 4.6 \mathrm{~mm}$ column size). The mass-to-charge $(\mathrm{m} / \mathrm{z})$ ratio and the MALDI spectra for all the thiolated ONs are given in Supporting Information (SI, Table S1 and Figures S1-S3). Unmodified ONs (Sigma-Aldrich St. Louis, MO) were analyzed by ion-exchange HPLC, and used without purification.

The ONs used are listed in Table 1: thiolated 13- and 20-base DNA (Probes A, B, and C), fully complementary 13- and 20-base DNA

Table 1. Base Sequences of the 20-Base and 13-Base Oligonucleotides Used

\begin{tabular}{|c|c|c|}
\hline \multirow{12}{*}{$\begin{array}{l}\text { : } \\
\text { 今. } \\
\text { 今े }\end{array}$} & Thiolated Probe A & 5'-GG GGC AGT GCC TCA CAA CCT-C3-SH \\
\hline & Target A0 & 3'-CC CCG TCA CGG AGT GTT GGA \\
\hline & Target Al & 3'-CC CCG TCA CAG AGT GTT GGA \\
\hline & Target A2 & 3'-CC CCG TCA CGG ATG GTT GGA \\
\hline & Target A3 & 3'-CC CCG TCA CAG ATG GTT GGA \\
\hline & Target A4 & 3'-CC CCG CCA CAG AGG GTT GGA \\
\hline & Thiolated Probe B & 5'-GC ACT GTA TGT CTG TAC CAT-C3-SH \\
\hline & Target $\mathrm{B} 0$ & 3'-CG TGA CAT ACA GAC ATG GTA \\
\hline & Target B1 & 3'-CG TGA CAT AGA GAC ATG GTA \\
\hline & Target B2 & 3'- CG TGA CAT ACA GGT ATG GTA \\
\hline & Target B3 & 3'- CG TGA CAT AGA GGT ATG GTA \\
\hline & Target B4 & 3'- CG TGA AAT AGA GAT ATG GTA \\
\hline \multirow{2}{*}{ 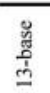 } & Thiolated Probe C & 5'-HS-C6-CGC ATT ATT ACG C \\
\hline & Target $\mathrm{C} 0$ & 3'-GCG TAA TAA TGC G \\
\hline
\end{tabular}

(Targets A0, B0, and C0), and 20-base DNA containing 1, 2, and 3 mismatches indicated in gray in the target sequences.

2.2. Melting Temperatures. Thermal denaturation temperatures $\left(T_{\mathrm{m}}\right.$ values $\left./{ }^{\circ} \mathrm{C}\right)$ were measured under different buffer conditions (standard cond.: $10 \mathrm{mM} \mathrm{NaCl}$, adjusted to $\mathrm{pH} 7.0$ with $50 \mathrm{mM}$ $\mathrm{KH}_{2} \mathrm{PO}_{4} / \mathrm{K}_{2} \mathrm{HPO}_{4}$ ), using a UV/vis spectrophotometer equipped with a Peltier temperature programmer. Concentrations of ONs were calculated using the following extinction coefficients $\left(\mathrm{OD}_{260} / \mu \mathrm{mol}\right.$, quartz optical cells with a path-length of $1.0 \mathrm{~cm}$ ): G, 10.5; A, 13.9; T, 7.9; C, 6.6. A solution containing $1 \mu \mathrm{M}$ probe $\mathrm{ON}$ and $1 \mu \mathrm{M}$ target ONs was mixed with the $T_{\mathrm{m}}$-buffer, denatured by heating at $85^{\circ} \mathrm{C}$ for $15 \mathrm{~min}$, and annealed through cooling to $10{ }^{\circ} \mathrm{C}$. The samples were then heated to $80{ }^{\circ} \mathrm{C}$ with a ramp of $1.0{ }^{\circ} \mathrm{C} / \mathrm{min}$ recording the absorbance at $260 \mathrm{~nm}$ with intervals of $0.5^{\circ} \mathrm{C} . T_{\mathrm{m}}$ values were defined as the maximum of the first derivatives of the melting curve $\left(A_{260}\right.$ vs temperature). The reported thermal denaturation temperatures are average values of two measurements within $\pm 1.0{ }^{\circ} \mathrm{C}$. 
2.3. Electrodes. Single-crystal $\mathrm{Au}(111)$ bead electrodes $(2-3 \mathrm{~mm}$ diameter) prepared as described ${ }^{58,59}$ and checked by cyclic voltammetry in $0.1 \mathrm{M} \mathrm{H}_{2} \mathrm{SO}_{4}$ were used for voltammetry. $\mathrm{Au}(111)$ disc electrodes (SPL, The Netherlands \& MaTeck, Germany) were employed for in situ STM. The electrodes were cleaned prior to use by $\mathrm{H}_{2}$ flame annealing and quenched in Millipore water saturated with $\mathrm{H}_{2}$.

2.4. Sample Preparation. Full self-assembled monolayers of ss ONs were prepared by immersing the freshly cleaned $\mathrm{Au}(111)$ electrode overnight in a solution of $1 \mu \mathrm{M}$ thiolated (13- or 20-base) ss$\mathrm{ON}$ containing $50 \mathrm{mM} \mathrm{KH} \mathrm{PO}_{4} / \mathrm{K}_{2} \mathrm{HPO}_{4}, 10 \mathrm{mM} \mathrm{NaCl}$, and $10 \mathrm{mM}$ $\mathrm{Spd} \cdot 3 \mathrm{HCl}(\mathrm{pH} 6.5)$. The ds-ON monolayers were prepared from 1 $\mu \mathrm{M}$ thiolated $\mathrm{ON}$ probe and $1.2 \mu \mathrm{M}$ of the complementary strand, in the same electrolyte solution including $10 \mathrm{mM}$ Spd. After $1-2 \mathrm{~h}$ at room temperature (time needed for hybridization), the freshly cleaned $\mathrm{Au}(111)$ electrode was exposed to the ds-ON solution overnight. The ss- or ds- ON monolayer samples were washed in the electrolyte solution and then in Millipore water (to remove excess ONs), and mounted in the electrochemical or in situ STM cell.

Dilute ss-ON monolayers were prepared by first exposing the $\mathrm{Au}(111)$ electrode to $1 \mu \mathrm{M}$ thiolated ss-ON solution containing 50 $\mathrm{mM} \mathrm{KH} \mathrm{KH}_{4} / \mathrm{K}_{2} \mathrm{HPO}_{4}$ and $300 \mathrm{mM} \mathrm{NaCl}$ for $90 \mathrm{~min}$, and then immersing the $\mathrm{ON}$ monolayer formed into $1 \mathrm{mM}$ mercaptohexanol $(\mathrm{MCH})$ solution for $10 \mathrm{~min}$. A dilute ds-ON monolayer was prepared by further overnight soaking in a solution of $4 \mu \mathrm{M}$ complementary strand (same electrolyte buffer). After each immersion into an ON solution the electrode with a dilute ds-ON monolayer was rinsed in the electrolyte solution and then in Millipore water, and mounted in the cell. For intercalation of anthraquinone-2-sulfonic acid sodium salt, monohydrate (AQMS) into the DNA duplex, the ds-ON monolayer formed as described was exposed overnight to $5 \mathrm{mM}$ aqueous AQMS, then rinsed with Millipore water and transferred to the electrochemical cell containing AQMS-free electrolyte.

The three thiolated ON sequences used are shown in Table 1 . They were used alone and after hybridization with complementary ON target (Probes A0-B0-C0) or, in the case of 20-base ONs, with ON targets containing 1,2 , and 3 mismatches located as shown in Table 1 .

2.5. Cyclic Voltammetry. Cyclic and linear voltammograms were recorded using a three-compartment cell containing 1) $50 \mathrm{mM}$ $\mathrm{KH}_{2} \mathrm{PO}_{4} / \mathrm{K}_{2} \mathrm{HPO}_{4}$ and $300 \mathrm{mM} \mathrm{NaCl}(\mathrm{pH} 7.0)$ or 2) $50 \mathrm{mM}$ $\mathrm{KH}_{2} \mathrm{PO}_{4} / \mathrm{K}_{2} \mathrm{HPO}_{4}, 10 \mathrm{mM} \mathrm{NaCl}$, and $10 \mathrm{mM} \mathrm{Spd} \cdot 3 \mathrm{HCl}(\mathrm{pH} 6.5$ ) as electrolyte using an electrochemical Autolab PGSTAT12 system controlled by the GPES 4.9 software (Eco Chemie, Netherlands). A freshly prepared reversible hydrogen electrode (RHE) served as reference and a Pt wire as counter electrode. The electrolyte solution was degassed with Argon $(5 \mathrm{~N})$ for $1 \mathrm{~h}$ prior to electrochemical experiments. The reference electrode was calibrated against a saturated calomel electrode (SCE) after each experiment. Electrochemical potentials are reported versus SCE.

2.6. Scanning Tunneling Microscopy. A PicoSPM in situ STM microscope (Molecular Imaging) was used. Platinum wires served as reference and counter electrodes. The reference electrode was calibrated against a saturated calomel electrode (SCE) after each experiment. Electrochemically etched $\mathrm{W}$ tips $(\varnothing 0.25 \mathrm{~mm})$ coated with Apiezon wax served as scanning probe.

STM samples were prepared as for the electrochemical measurements. After soaking in the $\mathrm{ON}$ solution, the $\mathrm{Au}(111)$-electrodes were mounted in an in-house built liquid cell. Low tunnelling currents (35$80 \mathrm{pA}$ ) and modest bias voltages (ca. $0.5 \mathrm{~V}$ ) were generally used. Sample potentials were between $-0.65 \mathrm{~V}$ and $-0.15 \mathrm{~V}$ versus SCE.

\section{RESULTS}

3.1. Melting Temperatures. All melting temperatures are given in the Supporting Information, Table S2. A comparative diagram is shown in Figure 2. Spd was found to increase thermal stability for a 20-base DNA duplex low in salt and buffer $(10 \mathrm{mM} \mathrm{NaCl}) . T_{\mathrm{m}}$-values recorded in the presence of 5 , 10 , and $50 \mathrm{mM}$ Spd were compared with the reference $T_{\mathrm{m}}$ (no $\mathrm{Spd}$ ), and $T_{\mathrm{m}}$ was found to increase by 8,10 , and $12.5{ }^{\circ} \mathrm{C}$,

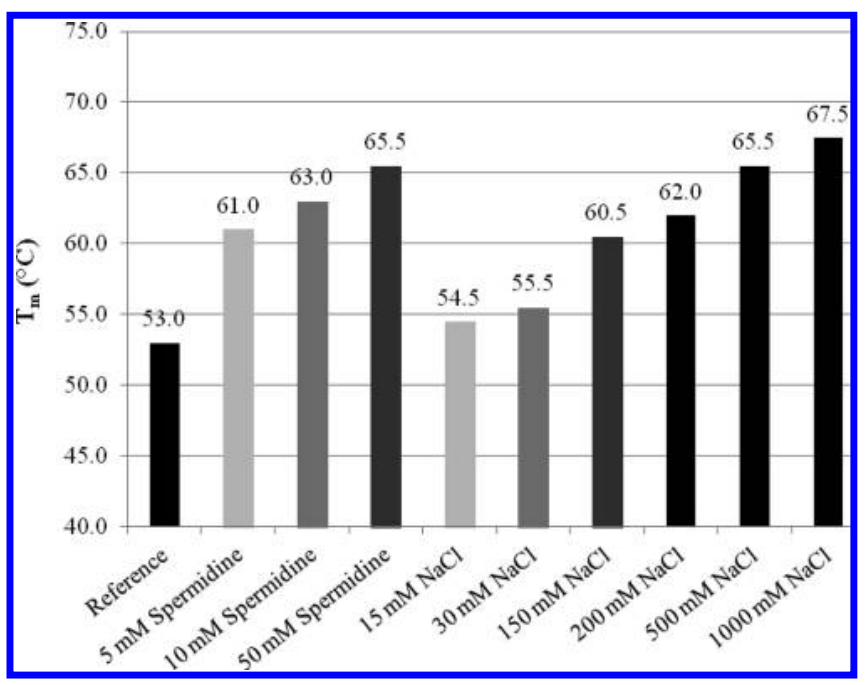

Figure 2. $T_{\mathrm{m}}$-values for fully matched 20-base ds DNA in the presence of different concentrations of Spd and $\mathrm{NaCl}$. All solutions contained 1 $\mu \mathrm{M}$ ds DNA, $10 \mathrm{mM} \mathrm{NaCl}$, and $50 \mathrm{mM} \mathrm{KH}_{2} \mathrm{PO}_{4} / \mathrm{K}_{2} \mathrm{HPO}_{4}(\mathrm{pH} \mathrm{7.0)}$, in addition to the salt indicated on the $x$ axis.

respectively (Figure 2). Under these conditions, the Spd charge is +3 and capable of neutralizing the negatively charged DNA backbone, resulting in increased $T_{\mathrm{m}}$-values. To clarify whether the stabilizing effect from Spd was only due to increased ionic strength, we recorded $T_{\mathrm{m}}$-values in $\mathrm{NaCl}$ concentrations equivalent to Spd with a charge of $+3\left(10 \mathrm{mM} \mathrm{Spd}^{3+}=30\right.$ $\mathrm{mM} \mathrm{Na}{ }^{+}$, Spd charges regarded as individual charges). Comparison of $T_{\mathrm{m}}$-values for fully matched ds-DNA in equivalent ionic concentration of either $\mathrm{Spd}$ or $\mathrm{NaCl}$ shows that the Spd stabilizing effect cannot solely be caused by ionic strength (Figure 2, light gray, gray, dark gray). The difference between $\mathrm{Spd}$ and $\mathrm{NaCl}$ stabilization, however, gradually evens out as the salt concentration increases.

3.2. Electrochemistry. Antraquinone mono- (AQMS) and disulfonate (AQDS) have been extensively used as intercalating electrochemical redox probes. ${ }^{19}$ Merits are their negative charges that minimize competition from electrostatic binding to the polyanionic DNA backbone, leaving intercalation as a more competitive binding mode. Figure $3 \mathrm{~A}$ shows $\mathrm{CV}$ s of the 20-base ds-ON probe molecule (Probe A:Target A0) in the absence and presence of AQMS. A voltammetric peak specific to AQMS appears around $-425 \mathrm{mV}$ versus SCE, in accordance with reported observations. ${ }^{19}$ The signals were stable, but displayed variations from one electrode to another. This suggests that despite the formation of an open ds-ON structure into which the intercalating molecules can find their way, intercalation remains fragile by the nonrigid ds-ON configuration and by the electrostatic repulsion between the DNA backbone and the AQMS anion. The 13-base ds-ON showed a similar trend (Figure 3B).

Figure S4 in Supporting Information shows in situ STM images of the 20-base ds-ON (Probe A0: Target A0) in the absence of Spd, in two different aqueous media, one without $\mathrm{NaCl}$ and one with $50 \mathrm{mM} \mathrm{NaCl}$. The images show molecular scale features where the triangular $\mathrm{Au}(111)$-terraces are also visible and offer an impression of the local environment of a full thiolated ds-ON monolayer.

Polycation addition is expected to enhance the ds-based AQMS voltammetric peak but strong cation binding in the interfacial double layer region will also modify structural 

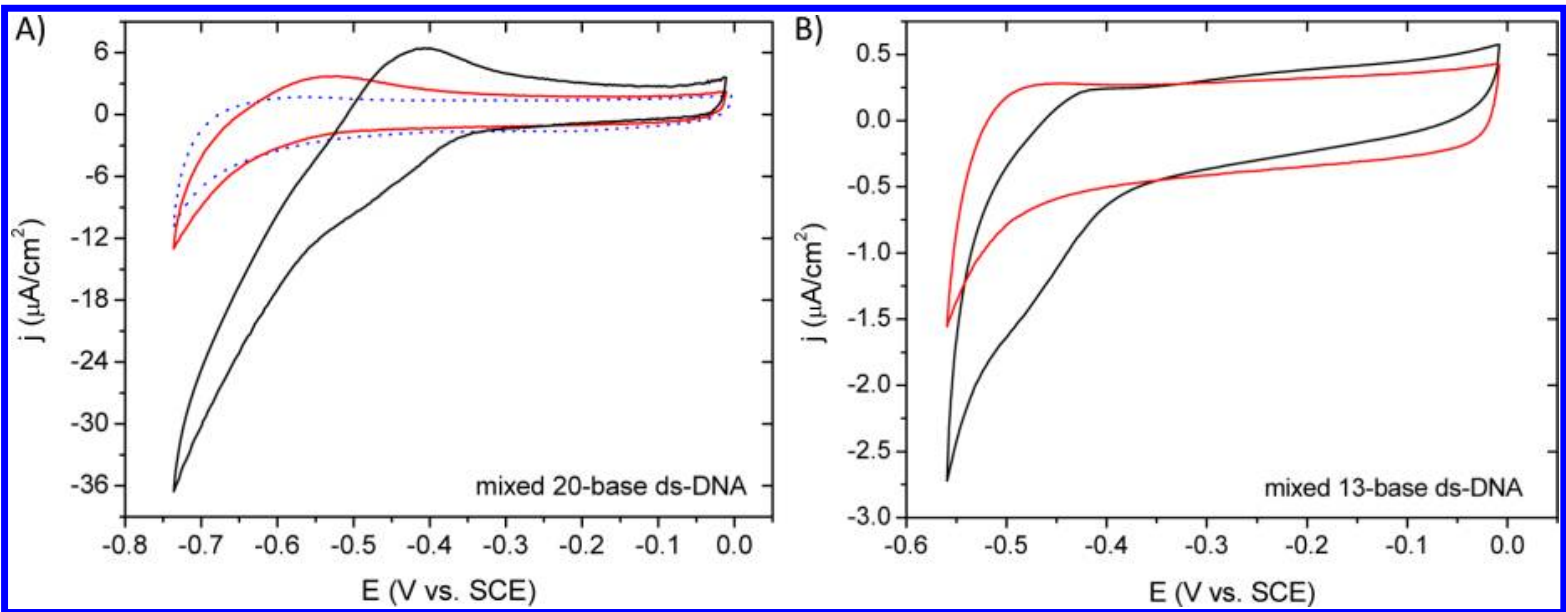

Figure 3. CVs of a dilute fully matched (A) 20-base ds-ON monolayer (Probe A:Target A0) and (B) 13-base ds-ON monolayer (Probe C:Target $\mathrm{CO}$ ) before (red curve) and after (black curve) exposure to $5 \mathrm{mM}$ AQMS solution on a Au(111)-electrode surface in $50 \mathrm{mM} \mathrm{KH}_{2} \mathrm{PO}_{4} / \mathrm{K}_{2} \mathrm{HPO}_{4}$ and $300 \mathrm{mM} \mathrm{NaCl}(\mathrm{pH} 7.0)$. Scan rate $100 \mathrm{mV} \mathrm{s}^{-1}$. The blue dotted curve shows a CV of a $\mathrm{MCH}$ monolayer exposed overnight to $5 \mathrm{mM}$ AQMS in the electrolyte solution ( $50 \mathrm{mM} \mathrm{KH}_{2} \mathrm{PO}_{4} / \mathrm{K}_{2} \mathrm{HPO}_{4}$ and $300 \mathrm{mM} \mathrm{NaCl}$, pH 7.0).

properties and organization of immobilized ONs, and the dependence of these properties on the electrochemical potential. To illuminate the potential dependent structural features of polycation binding, we therefore focused on surface ss- and ds-ONs after exposure to Spd. Spd-induced voltammetric peaks distinctive of the two forms were in fact observed for both ss-ON and ds-ON (Figure 4). The peaks appeared moreover in a potential range $(-300$ to $-500 \mathrm{mV}$ vs SCE) which overlaps with the AQMS peak potential in Spdfree solution.

Figure 4 shows voltammograms of the 20-base ss- and dsONs (Probe B: Target B0) in the absence of AQMS, but in the presence of $10 \mathrm{mM}$ Spd. A peak at $-480 \mathrm{mV}$, that is, close to the AQMS peak potential appears already for the ss-probe. A much weaker and broader peak appears in the same potential

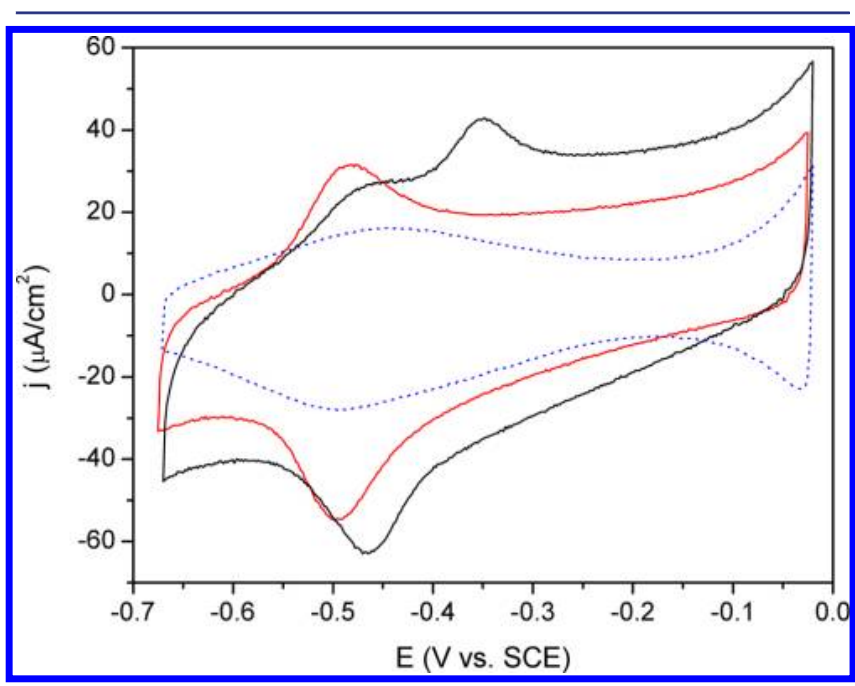

Figure 4. CVs of a full monolayer of thiolated 20-base ss-ON (Probe $\mathrm{B}$, red curve) and of a fully matched 20-base ds-ON (Probe B:Target B0, black curve) on a $\mathrm{Au}(111)$ electrode. $50 \mathrm{mM} \mathrm{KH} \mathrm{PO}_{4} / \mathrm{K}_{2} \mathrm{HPO}_{4}$, $10 \mathrm{mM} \mathrm{NaCl}$ and $10 \mathrm{mM} \mathrm{Spd} \cdot 3 \mathrm{HCl}\left(\mathrm{pH} \mathrm{6.5)}\right.$. Scan rate $1 \mathrm{~V} \mathrm{~s}^{-1}$. The blue dotted curve shows a $\mathrm{CV}$ for the bare $\mathrm{Au}(111)$-electrode exposed overnight to the same electrolyte solution $\left(50 \mathrm{mM} \mathrm{KH}_{2} \mathrm{PO}_{4} / \mathrm{K}_{2} \mathrm{HPO}_{4}\right.$, $10 \mathrm{mM} \mathrm{NaCl}$ and $10 \mathrm{mM}$ Spd-3HCl, pH 6.5) and same conditions but with no DNA. range, for the same electrolyte solution, including Spd but with no ON monolayer (dotted curve in Figure 4). The ds-form displays, however, a new peak when Spd is present, with a midpoint potential around $-395 \mathrm{mV}$.

The new Spd induced peak appears for both target $\mathrm{ON}$ sequences with the following features:

- The peak remains after multiple scanning and appears most strongly at higher scan rates and low ionic strength with gradual attenuation as the ionic strength $(\mathrm{NaCl})$ increases. This follows the pattern for the melting temperature $T_{\mathrm{m}}$.

- The peak height shows an approximately linear dependence of the scan rate indicative of monolayer behavior (Figure S5 in Supporting Information).

- Notably, the peak is sensitive to base pair mismatches. Figure 5 shows baseline corrected potential scans over

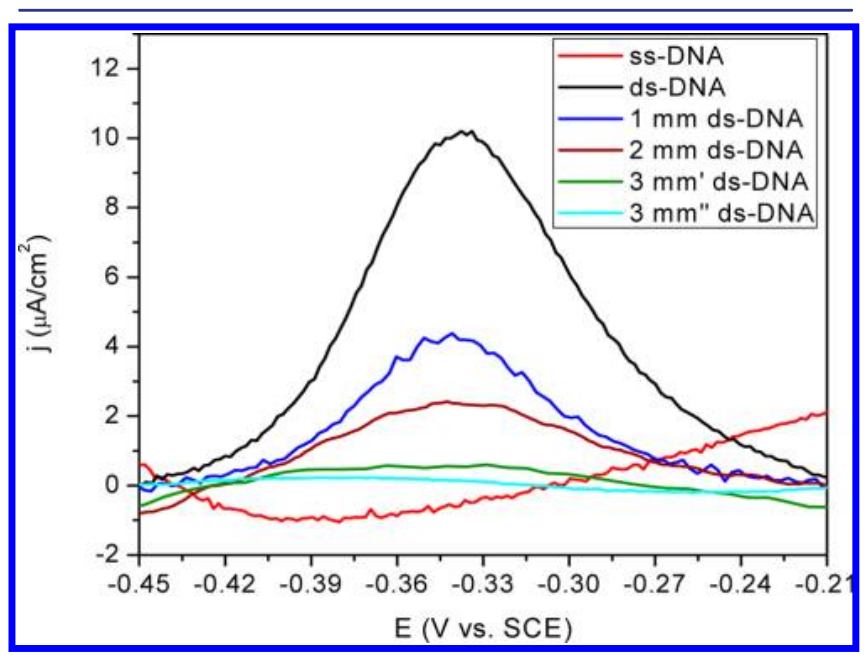

Figure 5. Linear scan voltammograms of full monolayers of thiolated 20-base ss-ON (Probe A, red curve), fully matched 20-base ds-ON (Probe A:Target A0, black), and 20-base ds-ONs with one, (Probe A: Target A1, blue), two (Probe A: Target A2, brown); and three (Probe $\mathrm{A}$ :Target $\mathrm{A} 3$ and $\mathrm{A} 4$, green and cyan, respectively) mismatches, on a $\mathrm{Au}(111)$-electrode. $50 \mathrm{mM} \mathrm{KH} \mathrm{PO}_{4} / \mathrm{K}_{2} \mathrm{HPO}_{4}, 10 \mathrm{mM} \mathrm{NaCl}$ and 10 $\mathrm{mM} \mathrm{Spd} \cdot 3 \mathrm{HCl}(\mathrm{pH} 6.5)$. Scan rate $0.5 \mathrm{~V} \mathrm{~s}^{-1}$. ds-DNA $3 \mathrm{~mm}^{\prime}$ and $3 \mathrm{~mm}^{\prime \prime}$ both display 3 mismatches, but at different sites. 
the peak potential range for 20-base ss-ON, fully matched 20-base pair ds-form, and for the 20-base pair ds-form with one, two, and three mismatches (all ONs are from sequence A, Table 1). Similar results were observed for the $\mathrm{ON}$ sequence $\mathrm{B}$. The signal is strongly attenuated for the mismatched ds-forms and has largely disappeared for triply mismatched ds. Peak disappearance was also observed when the mismatches were spread out over the $\mathrm{ON}$ sequence such as for the A4/B4 sequences, Table 1, and Figure S6 in Supporting Information.

The peak separation is about $120 \mathrm{mV}$ (scan rates in the range $\left.1 \mathrm{~V} \mathrm{~s}^{-1}\right)$. There is no redox group in these $\mathrm{ON}$ probes, and hence no Faradaic voltammetry in these potential ranges. The peak half-width is ca. $90 \mathrm{mV}$. The apparent charge of $8.6 \times 10^{-7}$ $\mathrm{C} \mathrm{cm}{ }^{-2}$ for ds-ON with no mismatches is $20-30 \%$ of what corresponds to a one-ET process for a densely packed monolayer as estimated either from reductive desorption or dense cylindrical $3 \mathrm{~nm}$ diameter packing. This supports a capacitive origin of the peak rooted in changes of the $\mathrm{ON}$ surface organization in the electrostatically complex interfacial electrode/ds-ON/electrolyte region around the peak potential.

These observations resemble observations in a study of the amino acid homocysteine. ${ }^{60}$ Like the ON/Spd complexes, homocysteine possesses a combination of positive and negative electrostatic charges, although the molecule is much simpler. This homologue of the amino acid cysteine displays a sharp capacitive peak on $\mathrm{Au}(111)$-electrode surfaces. In situ STM could associate directly the peak with lateral disorder/order transitions at the peak potential, assigned to structural bending of the homocysteine molecule with the ammonium group facing the electrode surface on the negative side and the carboxylate group on the positive side of the peak potential.

\section{DISCUSSION}

A variety of organic aromatic redox molecules and transition metal complexes covalently tethered or intercalated into variable-length and base composition ds-ONs have been exploited as probes for photoinduced long-range charge hopping along the ds-ON axis. ${ }^{1-13}$ Long-range electrochemical ET has also been probed ${ }^{16-22,61-65}$ and voltammetric signals sensitive to mismatching observed. Direct association with charge hopping is not as obvious at these much lower energies, although ligand-based electrochemical radical formation of intercalated transition metal complexes have also been reported. ${ }^{65}$ Electrochemical probes have included methylene blue $\left(E^{0} \approx-250 \mathrm{mV}\right.$; equilibrium or midpoint potentials vs SCE), ${ }^{61,62}$ daunomycin $\left(E^{0}=-600 \mathrm{mV}\right),{ }^{16}$ anthraquinone mono- and -disulfonate $\left(E^{0} \approx-450 \mathrm{mV}\right),{ }^{19}$ Redmond red $\left(E^{0}\right.$ $\approx-280 \mathrm{mV}),{ }^{63}$ and Nile Blue $\left(E^{0} \approx-200 \mathrm{mV}\right),{ }^{18}$ as well as several intercalating complexes of ruthenium and osmium $\left(E^{0}\right.$ $\approx-(450-550) \mathrm{mV})^{61,64}$ or iridium $\left(E^{0} \approx-250 \mathrm{mV}\right)^{65}$ with aromatic ligands. Common to the electrochemical redox probes is a significantly negative equilibrium redox potential range that includes the capacitive Spd-induced peak potential reported presently.

Polycation binding to the polyanion ON-backbone evokes significant changes in the $\mathrm{ON}$ structure and dynamics reflected in physical properties ${ }^{47-56}$ ranging from ds-ON melting temperatures and vibrational spectral properties to columnar stacking. Electrostatic polycation binding would invariably be reflected also in ss- and ds-ON behavior at the electrochemical
metal/ON/aqueous buffer interface and cause interfacial structural reorganization sensitive to external electric field effects, with electrochemical fingerprint features around the potential of zero charge. Features such as these are inherent in the Spd-induced capacitive voltammetric peak.

The reported data disclose a voltammetric peak of monolayers of thiolated 20-base pair ONs. The peak is observed for two different fully matched base pair sequences and is clearly associated with binding of Spd. The peak is specific to the ds-form, and sensitive to base pair mismatching, largely disappearing after three differently distributed mismatches. The peak charge is significantly smaller than for a full Faradaic monolayer which also suggests a capacitive origin and structural reorganization of fully matched ds-ON monolayers around the peak potential. The peak sensitivity to ds-matching perhaps suggests a novel route to detection of ds-ON formation and base pair mismatches using also other organic polycations such as spermine or putrescine. Multiply charged metallic cations might also induce capacitive peaks, but $\mathrm{Mg}^{2+}$ was shown in the present study to be inactive.

The Spd-induced electrochemical capacitive signal prompts conjecturing bridging to the general crucial role of organic polycations in DNA stacking and precipitation. As noted, Spd and other polycations induce the formation of columnar liquidcrystalline DNA aggregates. ${ }^{51,52,54,56,66,67}$ Aggregate formation is reflected in a variety of physical properties with far-reaching implications for polyamine biosynthetic activity and protein free intermolecular DNA communication. Spd binding to long ds-strands has been shown to involve large binding constants, sensitive inter-helix distances, and Spd-helix bridging even to the extent of electrostatic overscreening and ionic condensation. ${ }^{48}$ As also noted, the driving forces for intermolecular DNA aggregation are, however, much stronger for DNA strands which are much longer than used in the present study. These longer strands ( $>100 \mathrm{bps}$ ) have therefore primarily been in focus in most approaches to DNA aggregation and columnar stacking. It will be of interest to explore these features for shorter strands where single-crystal electrochemistry, in situ STM, and single-molecule conductivity can offer approaches to DNA organization and stacking in well-defined local environments.

As a final note, the increased ds-ON stability on Spd binding could also increase the stability of ds-ONs with intercalated redox probes. As noted, the redox potentials of many electrochemical intercalators are, however, not far from the Spd-induced capacitive peak. A capacitive Spd-peak also depends on the general state of the electrode. Single-crystal $\mathrm{Au}(111)$-electrodes and ultraclean conditions were used in the present study, whereas polycrystalline electrodes were used in all previous studies based on Au-electrodes. Packing and structural reorganization of target molecules as complex as the ds-ONs are therefore different, and both structurally caused voltammetric peaks and Faradaic redox probe signals may be located at different potentials in different local environments such as single-crystal and polycrystalline electrode surfaces. Surface structural properties of short immobilized ONs will also depend on the ON length with a corresponding distance dependence of the capacitive peak. The dependence of the structural capacitive properties of the electrode/ds-ON/ aqueous buffer interface would, however, be insignificant beyond a certain length. This might resemble distance independence of Faradaic signals of an intercalator. These 
two entirely different physical origins of DNA-based voltammetric signals must of course be distinguished.

\section{ASSOCIATED CONTENT}

\section{S Supporting Information}

Base sequences and MALDI-MS analysis of the oligonucleotides tested; MALDI-MS spectra of the thiolated Probe A; MALDI-MS spectra of the thiolated Probe B; MALDI-MS spectra of the thiolated Probe C; $T_{\mathrm{m}}$ values for 20-base ds-DNA in the presence of different concentrations of spermidine (Spd), and $\mathrm{NaCl}$; in situ STM images of a monolayer of 20-base dsON (Probe A: Target A0, $1 \mu \mathrm{M}: 2 \mu \mathrm{M}$ ) on Au(111)-electrode surface, (anodic) peak height $i_{\text {peak }}$ vs scan rate $\nu$ for a fully matched 20-base ds-DNA (Probe A:Target A0, no mismatches); CVs of triply mismatched 20-base ds-ONs on a $\mathrm{Au}(111)$ electrode. This material is available free of charge via the Internet at http://pubs.acs.org.

\section{AUTHOR INFORMATION}

\section{Corresponding Author}

ju@kemi.dtu.dk

Notes

The authors declare no competing financial interest.

\section{ACKNOWLEDGMENTS}

We would like to thank the Villum Kann Rasmussen Foundation for financial support and the Otto Mønsted Foundation for an Otto Mønsted visiting professorship to R.J.N. Professor Jesper Wengel, University of Southern Denmark is thanked for helpful discussions.

\section{REFERENCES}

(1) Turro, N. J.; Barton, J. K. I. Biol. Inorg. Chem. 1998, 3, 201-209.

(2) O’Kelley, S.; Barton, J. K. Science 1999, 283, 375-381.

(3) Charge Transfer in DNA: From Mechanism to Application; Wagenknecht, H.-A., Ed.; Wiley-VCH: Weinheim, 2004.

(4) (a) Long-Range Charge Transfer in DNA I; Schuster, G. B. Ed.; Topics in Current Chemistry 236; Springer: New York, 2004. (b) Long-Range Charge Transfer in DNA II; Schuster, G. B., Ed.; Topics in Current Chemistry 237; Springer: New York, 2004.

(5) O’Neill, M. A.; Barton, J. K. I. Am. Chem. Soc. 2004, 126, 1147111483.

(6) O'Neill, M. A.; Barton, J. K. Sequence Dependent DNA Dynamics: The Regulator of DNA-Mediated Charge Transport. In Charge Transfer in DNA: From Mechanism to Application; Wagenknecht, H.-A., Ed.; Wiley-VCH: Weinheim, 2004; Chapter 2, pp 27-75.

(7) Wagenknecht, H-.A. Angew. Chem. 2003, 42, 2454-2460.

(8) Carrell, T.; von Meltzer, M. Excess Electron Transfer in DNA Probed with Flavin and Thymine Dimer-Modified Oligonucleotides. In Charge Transfer in DNA: From Mechanism to Application; Wagenknecht, H.-A., Ed.; Wiley-VCH: Weinheim, 2004; Chapter 3, pp 77-91.

(9) Kawai, K.; Kodera, H.; Majima, T. I. Am. Chem. Soc. 2010, 132, 627-630.

(10) Park, M. J.; Fujitsuka, M.; Kawai, K.; Majima, T. J. Am. Chem. Soc. 2011, 133, 15320-15323.

(11) Lewis, F. D.; Kalgutkar, R. S.; Wu, Y.; Liu, X.; Liu, J.; Hayes, R. T.; Miller, S. E.; Wasielewski, M. R J. Am. Chem. Soc. 2000, 122, 12346-12351.

(12) Lewis, F. D.; Letsinger, R. L.; Wasielewski, M. R. Acc. Chem. Res. 2001, 34, 159-170.

(13) Genereux, J. C.; Barton, J. K. Chem. Rev. 2010, 110, 1642-1662.

(14) Conwell, E. M.; Rakhmanova, S. V. Proc. Natl. Acad. Sci. U.S.A. 2000, 97, 4556-4560.
(15) Kinz-Thompson, C. D.; Conwell, E. M. J. Phys. Chem. C 2010, $114,1663-1666$

(16) O’Kelley, S.; Jackson, S. M.; Hill, M. G.; Barton, J. K. Angew. Chem. Int. Ed. 1999, 38, 941-945.

(17) Boal, A. K.; Barton, J. K. Bioconiugate Chem. 2005, 16, 312-321.

(18) Slinker, J. D.; Muren, N. B.; Renfrew, S. E.; Barton, J. K. Nat. Chem. 2011, 3, 228-233.

(19) Wong, E. L. S.; Gooding, J. I. Anal. Chem. 2003, 75, 3845-3852.

(20) Wong, E. L. S.; Chow, E.; Gooding, J. I. Langmuir 2005, 21, $6957-6965$

(21) Wong, E. L. S.; Gooding, J. J. J. Am. Chem. Soc. 2007, 129, $8950-8951$

(22) Hill, M. G.; Kelley, S. O. Electrochemistry at the DNA/ Electrode Interface: New Approaches to Nucleic Acid Biosensing. In Bioinorganic Electrochemistry; Hammerich, O., Ulstrup, J., Eds.; Springer: Guilford, U.K., 2008; Chapter 5, pp 129-160.

(23) Yang, G.-Z.; Ling, L.-S.; Wan, L.-J.; Fang, X.-H.; Bai, C.-L. J. Nanosci. Nanotechnol. 2004, 4, 561-564.

(24) Oshiro, T.; Maeda, M. Chem. Commun. 2010, 46, 2581-2583.

(25) Hansen, A. G.; Salvatore, P.; Karlsen, K. K.; Nichols, R. J.; Wengel, J.; Ulstrup, J. Phys. Chem. Chem. Phys. 2012, DOI: 10.1039/ C2CP42351K.

(26) Xu, B.; Zhang, P.; Li, X.; Tao, N. Nano Lett. 2004, 4, 11051108.

(27) Hihath, J.; Xu, B.; Zhang, P.; Tao, N. Proc. Natl. Acad. Sci. U.S.A. 2005, 102, 16979-16983.

(28) Van Zalinge, H.; Schiffrin, D. J.; Bates, A. D.; Ulstrup, J.; Nichols, R. I. ChemPhysChem 2006, 7, 94-98.

(29) Van Zalinge, H.; Schiffrin, D. J.; Bates, A. D.; Starikov, E. B.; Wenzel, W.; Nichols, R. I. Angew. Chem. Int. Ed. 2006, 45, 54995502.

(30) Cohen, H.; Nogues, C.; Ullien, D.; Daube, S.; Naaman, R.; Porath, D. Faradav Discuss. 2006, 131, 367-376.

(31) Gray, H. B.; Winkler, J. R. Proc. Natl. Acad. Sci. U.S.A. 2005, 102, 3534-3539.

(32) Winkler, J. R.; Dunn, A. R.; Hess, C. R.; Gray, H. B. Electron Tunneling through Iron and Copper Proteins. In Bioinorganic Electrochemistry; Hammerich, O., Ulstrup, J., Eds.; Springer: Guilford, U.K., 2008; Chapter 1, pp 1-23.

(33) (a) Armstrong, F. A. Curr. Opin. Chem. Biol. 2005, 9, 110-117. (b) Armstrong, F. A.; Hirst, J. Proc. Natl. Acad. Sci. U.S.A. 2011, 108, 14049-14054.

(34) Léger, C.; Bertrand, P. Chem. Rev. 2008, 108, 2379-2438.

(35) Bioinorganic Electrochemistry; Hammerich, O.; Ulstrup, J., Eds.; Springer, Guilford, U.K., 2008.

(36) Zhang, J.; Kuznetsov, A. M.; Medvedev, I. G.; Chi, Q.; Albrecht, T.; Jensen, P. S.; Ulstrup, J. Chem. Rev. 2008, 108, 2737-2791.

(37) Bonanni, B.; Andolfi, L.; Bizarri, A. R.; Cannistraro, S. R. J. Phys. Chem. B 2007, 111, 5062-5075.

(38) Climent, V; Zhang, J.; Friis, E. P.; Østergaard, L. H.; Ulstrup, J. I. Phvs. Chem. C 2012, 116, 1232-1243.

(39) Kuznetsov, A. M. Charge Transfer in Physics, Chemistry and Biology; Gordon \& Breach: Reading, U.K., 1995.

(40) Kuznetsov, A. M.; Ulstrup, J. Electron Transfer in Chemistry and Biology: An Introduction to the Theory; Wiley: Chichester, U.K., 1999.

(41) Jortner, J.; Bixon, M.; Langenbacher, T.; Michel-Beyerle, M. E. Proc. Natl. Acad. Sci. U.S.A. 1998, 95, 12559-12765.

(42) Bixon, M.; Jortner, J. Chem. Phvs. 2006, 326, 252-258.

(43) Andres, P. R.; Schubert, U. S. Adv. Mater. 2004, 16, 1043-1046.

(44) Van Grondelle, R.; Novoderzhkin, V. C. Phys. Chem. Chem. Phys. 2006, 8, 793-807.

(45) Porath, D; Bezryadin, A.; de Vries, S.; Dekker, C. Nature 2000, 403, 635-638.

(46) Kuznetsov, A. M.; Ulstrup, J. Charge Transport of Solute Oligonucleotides in Metallic Nanogaps-Observations and Some Puzzles. In Bioinorganic Electrochemistry; Hammerich, O., Ulstrup, Eds.; Springer: Guilford, U.K., 2008; Chapter 6, pp 161-205.

(47) Kornyshev, A. A.; Leikin, S. Phvs. Rev. Lett. 2001, 86, 36663669. 
(48) A. A. Kornyshev, A. A.; D. J. Lee, D. J.; S. Leikin, S.; Wynveen, A. Rev. Mod. Phvs. 2007, 79, 943-996.

(49) Nezt, R; Andelman, D. Phvs. Repts. 2003, 380, 1-95.

(50) Besteman, K.; Van Eljk, K.; Lemay, S. G. Nat. Phys. 2007, 3, 641-644.

(51) Pelta, J.; Livolant, F.; Sikorav, J.-L. J. Biol. Chem. 1996, 271, $5656-5662$.

(52) Bloomfield, V. A. Curr. Opin. Struct. Biol. 1996, 6, 334-331.

(53) Liu, D.; Wang, C.; li, J.; lin, Z.; Tan, Z.; Bai, C. J. Biomol. Struct. Dyn. 2000, 18, 1-9.

(54) Matulis, D.; Rouzina, I.; Bloomfield, V. A. I. Mol. Biol. 2000, 296, $1053-1063$.

(55) Mehdinia, A.; Kazemi, S. H.; Bathaie, S. Z.; Alizadeh, A.; Shamsipur, M.; Mousavi, M. F. I. Pharm. Biomed. Anal. 2009, 49, 587593.

(56) Baldwin, G. S.; Brooks, N. J.; Robson, R. E.; Wynveen, A.; Goldar, A.; Leikin, S.; Seddon, J. M.; Kornyshev, A. A. J. Phys. Chem. B 2008, 112, 1060-1064.

(57) Beaucage, S. L.; Caruthers, M. H. Current Protocols in Nucleic Acid Chemistry; John Wiley \& Sons, Inc.: New York, 2001; pp 3.3.13.3.20.

(58) Hamelin, A. I. Electroanal. Chem. 1996, 407, 1-11.

(59) Chi, Q.; Zhang, J.; Friis, E. P.; Andersen, J. E. T.; Ulstrup, J. J. Electrochem. Commun. 1999, 1, 91-96.

(60) Zhang, J.; Demetriou, A.; Welinder, A. C.; Albrecht, T.; Nichols, R. J.; Ulstrup, J. Chem. Phvs. 2005, 319, 210-221.

(61) Wong, E. L. S.; Erokhin, P.; Gooding, J. J. Electrochem. Commun. 2004, 6, 648-654.

(62) Pheeney, C. G.; Barton, J. K. Lanomuir 2012, 28, 7063-7070 and references therein.

(63) Buzzeo, M. C.; Barton, J. K. Bioconiugate Chem. 2008, 19, 21102112.

(64) Gorodetsky, A. A.; Barton, J. K. Langmuir 2006, 22, 7917-7922.

(65) Stinner, C.; Wightman, M. D.; Kelley, S. O.; Hill, M. G.; Barton, I. K. Inorg. Chem. 2001, 40, 5245-5250.

(66) Raspaud, E.; Olvera de la Cruz, M; Sikorac, J.-L.; Livolant, F. Biophvs. I. 1998, 74, 381-393.

(67) Raspaud, E.; Durand, D.; Livolant, F. Biophys. I. 2005, 88, 392403. 